\title{
PEMBAHARUAN HUKUM YANG MENDUKUNG KONDUSIFITAS IKLIM USAHA
}

\author{
Adi Sulistiyono \\ Fakultas Hukum Universitas Sebelas Maret \\ email: adi_sumo@yahoo.co.id
}

\begin{abstract}
This writing aims to give explain about the urgentcy of law reform on the development economic. In the next stage the umbrella law that exist will create the conducivity of business climate that also be a demand of economic. On the culmination sustainble economic law development, do develop not again doing 'disassembly' clauses in the legislation or making ne statute, but also attent and empower any aspect such as: reforms the substance of economic law, available of dispute resolution mechanism that authoritative and efficient, nationalism of legislator, and legal politics of president and vice president that makes law as general that guide economic activities conduciveness and firmly punish for the offenders destroy economic of nation. The all activities has done consistent based on vision and mission the government today and RPJPM. With this approach be ecpected developing economic law will be able to improve of national competitiveness, make high economic growth and also be law as guiding radar or guide of economic growth quality to decrease of poverty, press unemployment, and welfare the people
\end{abstract}

Keyword: law reform, business climate, and conducive.

\begin{abstract}
Abstrak
Penulisan berikut bertujuan memberikan penjelasan mengenai urgensi pembaharuan hukum terhadap perkembangan bidang ekonomi. Pada tahap selanjutnya payung hukum yang eksis akan menciptakan kondusifitas iklim usaha yang tentu saja menjadi tuntutan bagi bidang ekonomi. Pada kulminasi inilah pembangunan hukum ekonomi berkelanjutan (sustainable economic law development), melakukan pembangunan tidak lagi sekedar melakukan 'bongkar pasang' pasal-pasal dalam perundang-undangan atau pembuatan undang-undang baru saja, tapi juga memerhatikan dan memberdayakan aspek yang lain yang mencakup: reformasi substansi hukum ekonomi; tersedianya mekanisme penyelesaian sengketa yang berwibawa dan efisien; nasionalisme anggota Legislatif; dan adanya politik hukum presiden dan wakil presiden yang menjadikan hukum sebagai panglima yang memandu aktifitas ekonomi yang kondusif dan tegas menghukum bagi pelanggar hukum yang merusak ekonomi bangsa. Semua aktifitas tersebut dilakukan secara konsisten sesuai visi dan misi pemerintahan saat ini dan RPJMN. Dengan pendekatan tersebut diharapkan pembangunan hukum ekonomi akan mampu mewujudkan daya saing bangsa, menghasilkan pertumbuhan ekonomi yang tinggi, dan juga mampu menjadikan
\end{abstract}


hukum sebagai radar pemandu atau pengarah agar pertumbuhan ekonomi agar berkualitas untuk mengurangi kemiskinan, menekan angka pengangguran, dan menyejahterakan rakyat.

Kata kunci: pembaharuan hukum, iklim usaha, kondusif.

\section{A. Pendahuluan}

Kesadaran untuk memberikan posisi penting dan strategis merupakan langkah awal yang baik untuk menjadikan hukum sebagai variabel penting dalam menunjang keberhasilan bidang ekonomi. Pandangan ini menolak bahwa hukum semata-mata dipahami dari sudut normatif belaka, sedangkan pembangunan ekonomi dilihat sebagai bagian yang tidak utuh dari gejala sosial yang timbul di masyarakat (Lili Rasjidi, Ira Thania Rasjidi, 2002: 60). Tanpa adanya kesadaran tersebut, tampaknya sulit bagi bidang ekonomi untuk berkontribusi bagi pembangunan bangsa. Dengan lain perkataan, bahwa lembaga-lembaga hukum yang baik merupakan prasyarat bagi pertumbuhan dan pembangunan ekonomi jangka panjang (Daniel Berkowitz, tt:1). Pandangan senada dikemukakan pula oleh beberapa tokoh ekonom dunia dengan memberi tempat yang strategis bagi hukum dalam mendukung ekonomi suatu bangsa (Brian Z. Tamanaha, 1995:470-486). Ekonom Prancis Jean Tirole, pemenang hadiah Nobel Ekonomi 2014, berpandangan bahwa regulasi menciptakan iklim kondusif dalam rangka memerjinak sebagian kecil perusahaan-perusahaan kuat yang menguasai sektor industri. Tanpa regulasi, maka pasar monopoli semacam itu sering menghasilkan kondisi yang tidak diinginkan secara sosial, seperti harga yang lebih tinggi dibandingkan dengan harga yang seharusnya berdasarkan ongkos produksi, atau perusahaan bertahan dengan menutup masuknya perusahaan baru dan yang lebih produktif.

Peran pemerintah yang memosisikan hukum sebagai faktor strategis yang menunjang dan mengendalikan sektor ekenomi menjadi langkah awal dalam membangun kesadaran akan arti pentingnya hukum sebagai alat untuk memfasilitasi kemajuan ekonomi. Fasilitasi ini sesungguhnya beragam dalam agenda pembangunan, antara lain seperti yang digagas oleh Douglas North dan Max Weber. Kedua pemikir ini memuja aktor swasta dalam pembangunan. North berpandangan, hukum diperlukan untuk memfasilitasi terwujudnya 
"protection of property rights and enforcement of contracts lowers transaction costs for exchange and allows resources to be transferred to those who can use them in the most productive fashion.” Sementara Weber menekankan hukum sebagai "toward individual decisionmakers needing to plan their affairs" (Douglass North, 1990:10).

Arti penting memahami penempatan hukum demikian ini, berakibat pada strategi pembangunan hukum yang dilakukan oleh pemerintah (Jonker Sihombing, 2010:110). Pada awal kepemimpin Presiden Soeharto melalui Rencana Pembangunan Lima Tahun (Repelita) I telah muncul kesadaran bahwa pembangunan ekonomi tanpa pembangunan hukum akan sia-sia (Rizal Mallarangeng, 2002: 60-61). Namun, dalam Garis-garis Besar Haluan Negara (GBHN) bidang hukum hanya ditempatkan sebagai salah satu subsistem politik. Pemerintah memberi hukum ruang tersendiri dan lepas dari bidang politik ketika penyusunan GBHN 1993 dan GBHN 1997. Pada era reformasi, pembangunan hukum pada Rencana Pembangunan Jangka Panjang Nasional (RPJPN) 2005 - 2025, terdapat dalam misi nomor 2, dan ditempatkan sebagai salah satu program dalam rangka menunjang bangsa yang berdaya saing. Sedangkan untuk melihat posisi pembangunan hukum pada pemerintahan Presiden Joko Widodo, bisa diamati dalam rencana program Nawacita, sampai tersusunnya RPJMN Tahun 2015-2019 (RPJPN 2005-2025). Pertanyaannya, bagaimana rencana program nawacita dan RPJMN pemerintahan Presiden Joko Widodo memberikan wujud pembaharuan hukum yang mendukung kondusifitas iklim usaha?

\section{B. Hukum Sebagai Pondasi dan Radar Pemandu Iklim Usaha yang Kondusif}

Upaya untuk memberikan masukan yang relevan sebagai bahan dasar guna melakukan pembangunan ekonomi, memerlukan pengetahuan pendahuluan mengenai peran hukum terhadap bidang ekonomi. Melalui langkah ini, akan diketahui tuntutan bidang ekonomi terhadap bidang hukum yang selanjutnya dapat dijadikan masukan yang bermanfaat untuk menunjang pertumbuhan ekonomi. Posisi penting bidang hukum dalam perannya pada pembangunan di 
bidang ekonomi, telah diakui para pakar, diantaranya terdapat dalam tabulasi ragam pandangan pada tabel di bawah ini:

Tabel 1. Pandangan Para Pakar Berkait Peran Hukum Terhadap Ekonomi

\begin{tabular}{|c|c|c|}
\hline Peranan Hukum & Tujuan di Bidang Ekonomi & Tokoh \\
\hline $\begin{array}{l}\text { Urgensi Menciptakan } \\
\text { Kewibawaan Hukum }\end{array}$ & $\begin{array}{lr}\text { (1)menciptakan ikli ekonomi } \\
\text { yang kondusif dan untuk } \\
\text { menarik } & \text { investasi, } \\
\text { (2)menampung } & \text { dinamika } \\
\text { kegiatan } & \text { ekonomi, } \\
\text { (3)menciptakan } & \text { kegiatan } \\
\text { ekonomi yang efisien dan } \\
\text { produktif, (4)menciptakan daya } \\
\text { prediktabilitas akan tantangan di } \\
\text { masa mendatang }\end{array}$ & $\begin{array}{l}\text { Djunaedi } \\
\text { Hadisumarto } \\
\text { Hernado de Soto } \\
\text { Charles Himawan } \\
\text { Setiawan }\end{array}$ \\
\hline $\begin{array}{l}\text { Urgensi pemahaman } \\
\text { konsep } \\
\text { "transaction cost" }\end{array}$ & $\begin{array}{l}\text { Menemukan dan menentukan } \\
\text { strategi pengembangan maupun } \\
\text { penekanan pertumbuhan } \\
\text { ekonomi dengan mengendalikan } \\
\text { biaya-biaya non-produktif yang } \\
\text { harus ditanggung untuk } \\
\text { mencapai suatu transaksi } \\
\text { ekonomi }\end{array}$ & $\begin{array}{l}\text { Douglass C. } \\
\text { North }\end{array}$ \\
\hline $\begin{array}{l}\text { Urgensi } \\
\text { memertahankan } \\
\text { tingkat kepastian } \\
\text { dalam hubungan antar } \\
\text { manusia }\end{array}$ & $\begin{array}{lr}\text { Mewujudkan } & \text { pengharapan } \\
\text { individu-individu } & \text { dalam } \\
\text { kegiatan ekonomi } & \text { modern guna } \\
\text { menentukan } & \text { ekwilibrium } \\
\text { ekonomi dan } & \text { stabilitas } \\
\text { ekwilibrium yang telah dicapai }\end{array}$ & H. W. Robinson \\
\hline $\begin{array}{l}\text { Urgensi pembangunan } \\
\text { hukum yang } \\
\text { mempunyai daya } \\
\text { prediktabilitas, } \\
\text { prosedural, } \\
\text { pengkodivikasian } \\
\text { tujuan, penyeimbang, } \\
\text { pengakomodasian dan } \\
\text { daya penjernihan } \\
\text { status }\end{array}$ & $\begin{array}{l}\text { Pengembangan kehidupan } \\
\text { ekonomi }\end{array}$ & J.D. Ny Hart \\
\hline $\begin{array}{lr}\text { Urgensi pembangunan } \\
\text { hukum rang } \\
\text { mempunyai } & \text { stabilitas, } \\
\text { prediksi, } & \text { keadilan, } \\
\text { pendidikan, ran } & \text { dan } \\
\text { pengembangan khusus }\end{array}$ & $\begin{array}{l}\text { Agar hukum tidak menghambat } \\
\text { ekonomi }\end{array}$ & Burg's \\
\hline
\end{tabular}




\begin{tabular}{|llll|}
\hline dari sarjana hukum & & & \\
\hline Urgensi prioritas & Sebagai faktor pemandu, Adi Sulistiyono \\
pembangunan hukum & pembimbing, dan menciptakan & \\
(hukum ekonomi) oleh & iklim kondusif pada bidang & \\
penguasa (presiden) & ekonomi & & \\
\hline \hline $\begin{array}{l}\text { Urgensi memberangus } \\
\text { kelesuan teori secara }\end{array}$ & $\begin{array}{l}\text { Menciptakan ideologi yang } \\
\text { berperan seban A. Hadar } \\
\text { laten }\end{array}$ & dalam kegiatan ekonomi & \\
\hline
\end{tabular}

Sumber: Adi Sulistiyono, Muhammad Rustamaji. 2009. Hukum Ekonomi Sebagai Panglima. Sidoarjo: Masmedia Buana Putaka, hlm.23-25.

Mencermati tabel tersebut, pada masa Orde Baru, salah satu tekad pemerintahan pada awalnya adalah memulihkan kewibawaan hukum dan menegakkan rule of law. Hal itu ditunjang dengan semangat menjadi orde pembangunan, yang tidak mungkin terlaksana tanpa kegiatan-kegiatan ekonomi yng juga harus ditunjang bantuan luar negeri dan investasi asing. Namun ketika mencermati laporan Bappenas, meskipun pendanaan dari luar negeri tersebut selama bertahun-tahun diberi label sebagai pelengkap pendanaan pembangunan, namun setidak-tidaknya dalam 30 tahun, selama Repelita I sampai Repelita VI, jumlah pendanaan dari luar negeri tidak menurun besarannya. Kecenderungan ini mengarah pada situasi bahwa Indonesia menjadi tergantung pada pendanaan dari luar negeri. Dilihat dari persyaratannya, selama ini pendanaan luar negeri yang diterima pemerintah Indonesia berupa: hibah, pinjaman lunak, fasilitas kredit ekspor, pinjaman campuran (pinjaman bersyarat lunak dan fasilitas kredit ekspor), dan pinjaman komersial. Sedangkan menurut bentuk dan peruntukannya, dapat dikelompokkan menjadi hibah/pinjaman program dan hibah/pinjaman proyek. Berbagai jenis dan skema pendanaan tersebut diselenggarakan untuk menutup defisit pembiayaan pembangunan dan pembiayaan rutin (Bapenas, 2007:1). Adapun pembangunan hukum selama Orde Baru hanya dibiarkan mengalir begitu saja tanpa orientasi visi yang konsisten. Hal demikian misalnya terjadi dalam kasus regulasi penanaman modal. Dalam rangka mengendalikan kepentingan nasional serta meningkatkan kesejahteraan rakyat, ditempuh dengan berbagai kebijakan yang membatasi kegiatan penanaman modal asing. 
Namun pembatasan-pembatasan sebagaimana dimaksud disatu sisi akan mampu mengendalikan aktivitas penanaman modal asing agar tidak merugikan kepentingan nasional, tetapi di sisi lain dapat memberikan kesan kurangnya fleksibilitas pemerintah Indonesia yang dianggap merugikan kepentingan investor (Ana Rokhmatussa'dyah, Suratman, 2009:48). Bahkan, karena orientasi jangka pendek para elit politik, hukum hanya dijadikan sarana untuk melindungi kepentingan golongan elit tertentu yang punya akses kuat pada bidang ekonomi dan politik. Sebagai gambarannya, Masyarakat Transparansi Indonesia (MTI) merilis kajiannya mengenai, 79 dari 528 keputusan presiden yang dikeluarkan oleh Soeharto selama periode 1993-98, ternyata “bermasalah”. Keppres-keppres itu dinilai sebagai penyalahgunaan kekuasaan kepresidenan dan bertujuan untuk menguntungkan bisnis keluarga dan temanteman presiden. Dalam hasil studinya pada 1998, MTI mencatat ada 67 kepres yang bermasalah, diantaranya 32 Keppres pada sektor industri dan perdagangan, 24 pada proyek infrastuktur, 8 dalam bidang kehutanan dan perkebunan, serta 3 lainnya yang bisa digolongkan sebagai penyalahgunaan kekuasaan dan menyediakan fasilitas khusus bagi pejabat-pejabat negara (MTI, 1998:7).

Di era reformasi seperti sekarang ini, yaitu ketika masyarakat memunyai komitmen untuk melakukan reformasi di bidang politik, ekonomi, dan bidang hukum, kesalahan yang dilakukan pada masa lalu, ketika hukum senantiasa diterlantarkan, sebaiknya tidak terulang kembali. Untuk itu, tepat kiranya pada saat kondisi ekonomi Indonesia masih belum 'stabil' seperti sekarang ini, Pemerintahan Presiden Joko Widodo-Wapres Muhammad Yusuf Kalla, pada saat menyusun RPJMN Tahun 2015-2019 mulai memberikan skala prioritas utama pada pembangunan hukum, agar bisa digunakan sebagai pondasi dan radar pemandu para pelaku-pelaku ekonomi untuk menjalankan aktivitasnya (BPHN, 1996:7). Jadi hukum tidak sekedar dijadikan sarana untuk mewujudkan misi, tetapi menjadi bagian dari misi yang hendak diwujudkan.

Pengalaman Singapura juga patut menjadi bahan pembelajaran. Pada 1959, Lee Kuan Yew mengajak Bangsa Singapura bangkit dan bekerja keras 
agar pada tahun 1980 agar bisa menyamai bangsa Eropa. Pada saat itu tidak ada seorangpun yang percaya akan ajakan tersebut, karena waktu itu gross national product (GNP) per capita Singapura hanya 400 dollar AS. Langkah awal yang dilakukan Lee untuk merealisir visi tersebut adalah membuat hukum berwibawa, dan menjadikannya sebagai panglima aktivitas kegiatan ekonomi di Singapura. Faktanya, pada tahun 1990 (31 tahun sejak visinya dicanangkan) ketika Lee mengundurkan diri, GNP percapita Singapura meningkat 60 kali lipat atau 6000 persen, dan menjadi salah satu negara terkaya di dunia (Warren Fernandez dan Sumiko Tan, 1998:22).

Contoh selanjutnya, Presiden Argentina Nestor Kirchner, memimpin Argentina periode tahun 2003 sampai 10 Desember 2007. Kondisi Argentina sebelum Kirchner jadi presiden sangat parah dalam 15 hari (20 Desember 2001 - 3 Januari 2002) mempunyai lima Presiden ((Presiden Fernando de la Rua (1999-2001), Presiden Ramon Puerta (48 jam, 20 Desember 2001), Presiden Aldofo Rodgriguez Saa (22 Desember 2001-29 Desember 2001), Presiden Eudardo Camano (29 Desember 2001-1 Januari 2002), dan Presiden Eduardo Duahalde (1 Januari 2002-2003)), negara tak mampu membayar bunga utang yang sudah jatuh tempo 80 juta dollar AS, sementara utang luar negerinya lebih dari 9,5 milliar dollar AS, angka pengangguran mencapai 25 persen dari jumlah penduduk (36 juta jiwa), sedangkan nilai mata uang peso dideprisiasi 75 persen. Nestor Kirchner, seorang ahli hukum yang dibekali $a$ vision and strong leadership, selanjutnya mengambil langkah menjamin kepastian hukum, melakukan keberpihakan pada masyarakat miskin, membuat kebijakankebijakan ekonomi yang kondusif, mengontrol harga minyak, memberikan kredit pada warga miskin, dan membuat kebijakan ekonomi yang populis lainnya. Pada akhir pemerintahannya telah berhasil mengangkat Argentina dari keterpurukan, dengan pertumbuhan ekonomi meningkat rata-rata 8 persen pertahun, berhasil memerangi kemiskinan, memberikan lapangan kerja bagi 5 juta penduduk, membangun 3 juta rumah untuk rakyat miskin (Robert Bala, 2007:6, Tajuk Rencana Kompas, 2007:6, Kompas, 2007:7). 


\section{Faktor-faktor yang Potensial Menghambat Pembaharuan Hukum}

Iklim usaha merupakan faktor penting dan strategis untuk menunjang pembangunan ekonomi suatu bangsa. Menurut Nicholas Stern, iklim usaha atau investasi yang kondusif adalah iklim yang mendorong seseorang melakukan investasi dengan biaya dan resiko serendah mungkin di satu sisi, dan bisa menghasilkan keuntungan jangka panjang setinggi mungkin, di sisi lain (Nicholas Stern, 2001:5, Nicholas Stern, 2003:10). Sebagai contoh, beberapa studi menunjukkan bahwa di China dan India, sebagai hasil dari perbaikanperbaikan iklim investasi pada dekade 80 -an dan 90-an yang menurunkan biaya dan risiko investasi sangat drastis, maka investasi swasta sebagai bagian dari produk domestik bruto (PDB) meningkat hampir 200 persen (Tulus Tambunan, 2006:5).

Seiring dengan waktu dan dinamika kondisi ekonomi politik di Indonesia, berbagai sektor yang dinilai strategis mengalami penataan ulang atau deregulasi yang memungkinkan peranan lebih besar dari pihak swasta dalam pengelolaannya (Hilman Soelaiman. 2013:1). Peranan pemerintah bergeser menjadi penentu rambu-rambu dan pengawas sektor tersebut. Transisi tersebut dinilai kondusif sejalan dengan kondisi yang ada. Akan tetapi, tidak dapat dipungkiri pemerintah memiliki peran penting dalam mendorong masuknya investasi atau kapital dan menciptakan iklim investasi yang kondusif agar roda perekonomian terus berjalan. Apalagi, pembangunan ekonomi di Indonesia menghasilkan residu ketimpangan yang sulit diurai jika tak segera ditangani dengan serius. Sebagai gambaran, Ahmad Erani Yustika mengemukakan bahwa ampai tahun 2011 kue pembangunan masih terkonsentrasi di Jawa dan Sumatera. PDRB Jawa menyumbang sekitar 57,6\% dari total PDB dan Pulau Sumatera memberikan donasi sebesar 23,3\% (BPS, 2012). Dengan begitu, kedua pulau itu menguasai sekitar 82\% dari PDB Indonesia. Pulau Kalimantan, Sulawesi, Papua, Bali dan Nusa Tenggara hanya mendapat porsi sekitar 18\% (Ahmad Erani Yustika, 2012:6).

Kondisi yang berkembang saat ini ialah pemerintah belum mampu memberikan jaminan dan keamanan berusaha bagi investor, baik asing maupun 
lokal untuk mengembangkan usaha di daerah. Ada 3 (tiga) hal yang menghantui para investor dan para pionir yang mengembangkan usaha di suatu daerah yang tidak juga kunjung terjawab: (i) kepastian hukum dan jaminan keamanan, (ii) kondisi infrastruktur pendukung, serta (iii) birokrasi yang simpel, cepat, dan transparan.

Era Presiden Joko Widodo dan Muhammad Yusuf Kalla sebenarnya mempunyai modalitas awal yang baik dengan meningkatnya daya saing Indonesia di tingkat internasional. Indonesia mengalami peningkatan dalam hal daya saing global atau Global Competitiveness Index (GCI) periode 2014-2015 dari semula pada posisi 38 menjadi 34, atau naik 4 peringkat. Tahun sebelumnya peringkat daya saing Indonesia masih pada posisi 50. Peningkatan ini, walaupun sedikit, merupakan hal yang positif, terlebih ketika Indonesia akan menghadapi Masyarakat Ekonomi ASEAN (MEA) 2015. MEA yang dimaksudkan untuk menciptakan pasar tunggal Asean, ketika tidak dihadapi dengan kesiapan yang matang, disadari atau tidak akan memunculkan mitos baru bernama rasionalitas efisiensi komoditi, yang pada akhirnya memunculkan reifikasi (M.Rustamaji, 2015:99). Kondisi inilah yang oleh Hermawan Kertajaya dan para ekonom dikhawatirkan akan menurunkan daya saing Indonesia seperti kala digulirkannya AFTA (Asean Free Trade Area) dan CAFTA (China-Asean Free Trade Agreement) untuk kali pertama. Ketidaksiapan menjadikan Indonesia mengalami defisit perdagangan dan terjadinya depresiasi pasar lokal di Indonesia (Hermawan Kertajaya, 2014:7).

Namun kondisi ketidaksiapan Indonesia di masa lalu agak berbeda untuk saat ini. Menurut 4 (empat) survei dunia, menyatakan bahwa Indonesia menjadi tujuan investasi yang menarik bagi investor asing. Pertama, survei dari World Economic Forum itu sendiri yang menempatkan Indonesia pada rangking 34 sehingga secara daya saing mengalami peningkatan. Kedua, United Nations Conference on Trade and Development (UNCTAD) juga menempatkan Indonesia dijajaran atas negara tujuan investasi. Ketiga, survei dari Japan Bank for International Cooperation (JBIC) yang melakukan survei terhadap 500 perusahaan Jepang yang beropersi secara global menempatkan Indonesia 
sebagai negara paling menarik bagi investasi Jepang. Keempat hasil survei Inggris juga menempatkan Indonesia pada rangking nomor 3 untuk tujuan investasi. Empat survei ini membuktikan bahwa Indonesia memiliki modal yang besar untuk mampu bersaing pada tingkat global (Septian Deny, 2014).

Perbaikan kondisi yang mendukung iklim investasi juga secara empirik dapat dicermati pada adanya pemangkasan dari segi waktu, prosedur, dan biaya dalam memulai suatu usaha. Hal demikian merupakan indikasi adanya perbaikan untuk lebih memudahkan investor dan pengusaha. Sperlu disimak, salah satu upaya pemerintah era Presiden SBY dalam menguatkan iklim investasi adalah dengan menyederhanakan perijinan melalui pengefektifan fungsi pelayanan terpadu satu pintu. Pada 2013 telah terbangun 468 Pelayanan Terpadu Satu Pintu (PTSP) di 33 provinsi, 339 kabupaten, 93 kota, dan 3 kawasan perdagangan bebas dan pelabuhan bebas. Selain itu, pada rentang tahun 2012-2013 telah pula dilakukan penyederhanaan prosedur dalam bidang penanaman modal dengan terhubungnya Sistem Pelayanan Informasi dan Perizinan Investasi Secara Elektronik (SPIPISE) di 60 kabupaten/kota dengan Badan Koordinasi Penanaman Modal (BKPM). Sistem ini diharapkan dapat mengurangi rantai birokrasi dan pungutan liar, yang mengakibatkan ekonomi biaya tinggi. Kementerian Pendayagunaan Aparatur Negara dan Reformasi Birokrasi bekerja sama dengan Kementerian Dalam Negeri dapat memberikan insentif kepada provinsi dan kabupaten/kota yang menerapkan dan mendirikan BPPT tersebut.

Namun demikian tantangan pemerintahan Joko Widodo juga cukup berat, Bank Dunia merilis laporan bertajuk 'Doing Business 2015' mengenai daftar negara-negara yang hukumnya ramah terhadap investor. Singapura berada diurutan pertama poin 88,27; Indonesia mencatatkan ranking urutan 114 dengan poin 59,15. Posisi Indonesia ini jauh di bawah Malaysia yang berada pada posisi 18 dan Thailand 26. Bahkan Indonesia juga di bawah Vietnam yang berada di posisi 78 (World Bank, 2015:6). Penetapan ranking ini bisa dijadikan salah satu acuan Pemerintah Joko Widodo - Muhhamad Yusuf Kalla untuk 
menyiapkan perencanaan pembangunan ekonomi khususnya dalam rangka menciptakan iklim ekonomi yang kondusif bagi para investor.

Dengan demikian, menyimak beragam tarikan potensi dan ekses yang berpeluang muncul, terdapat beberapa faktor yang menjadi penghambat dilakukannya pembaharuan hukum dalam rangka menciptakan iklim usaha yang kondusif, antara lain;

1. Perilaku aparat penegak hukum yang tidak pro investasi, sebagi contoh: Kesalahan penggerebekan kantor Gameloft Jogja (Muhammad Manduh, 2014), perusahaan ekonomi kreatif yang bergerak di bidang pembuatan software game tingkat dunia, yang dilakukan polisi Jogjakarta karena menganggap sebagi tempat judi online merupakan tindakan yang menghambat iklim usaha.

2. Situasi politik di parlemen yang tidak kondusif. Anggota DPR 2014-2019 terbelah menjadi dua kelompok, yaitu: Koalisi Merah Putih dan Koalisi Indonesia Hebat yang mempunyai potensi konflik permanen.

3. Sinkronisasi politik hukum presiden dan wakil presiden dalam menjadikan hukum sebagai pondasi dan radar pemandu aktivitas ekonomi, dan konsisensi dalam pembrantasan korupsi.

4. Koordinasi dan komunikasi politik para menteri yang sering kurang sinkron tetang suatu program kebijakan.

5. Rendahnya budaya hukum dan profesionalitas aparatur perijinan dari tingkat pusat dan daerah,

6. Hakim belum mempunyai komitmen untuk menjadi pahlawan dalam pembangunan ekonomi, melalui putusan-putusan yang bervisi ekonomi mampu menjadikan pengadilan niaga menjadi mekanisme penyelesai sengketa kepailitan yang efektif dan efisien. Selain penyelesaian kepailitan masuk dalam variabel penilaian Doing Business 2015, terindikasi pula bahwa kepercayaan masyarakat pada Pengadilan Niaga untuk perkara kepailitan cenderung menurun. Data statistik penyelesaian perkara di Pengadilan Niaga seluruh Indonesia: Tahun 2010 : 235; Tahun 2011: 205 
perkara; Tahun 2012: 151 perkara; Tahun 2013: 147 perkara; Tahun 2014: 88 Perkara (Badilum, 2014).

7. Belum berkembangnya budaya penyelesaian bisnis menggunakan Alternative Dispute Resolution (ADR) dan Arbitrase di Indonesia (Adi Sulistiyono, 2006: 315-413).

\section{Peluang Pembangunan (Pembaharuan) Hukum}

Pembangunan hukum mempunyai makna yang lebih mennyeluruh dan mendasar dibandingkan dengan istilah pembinaan hukum atau pembaharuan hukum. 'Pembinaan hukum' lebih mengacu pada efisiensi, dalam arti meningkatkan efisiensi hukum. 'Pembaharuan hukum’ mengandung pengertian menyusun suatu tata hukum untuk menyesuaikan dengan perubahan masyarakat. Oleh karenanya, pembangunan hukum itu tidak hanya tertuju pada aturan atau substansi hukum, tetapi juga pada struktur atau kelembagaan hukum dan pada budaya hukum masyarakat, pendidikan hukum, politik hukum presiden dan wakil presiden, nasionalisme anggota legislatif, dan mekanisme penyelesaian sengketa bisnis yang efektif dan efisien.

Mencermati RPJPN Tahun 2005-2025, untuk mewujudkan visi Indonesia yang Mandiri, Maju, Adil dan Makmur, ditempuh melalui 8 (delapan) misi pembangunan nasional. Namun sayangnya di dalam RPJPN, hukum bukan merupakan salah satu misi pembangun, tetapi hanya ditetapkan sebagai variabel untuk mewujudkan misi kedua bangsa yang berdaya-saing dan mewujudkan misi ke yang ketiga, yaitu masyarakat demokratis berlandaskan hukum. RPJPN menggariskan bahwa untuk mewujudkan daya saing bangsa, pembangunan nasional dalam jangka panjang diarahkan untuk (a) mengedepankan pembangunan sumber daya manusia berkualitas dan berdaya saing; (b) memperkuat perekonomian domestik berbasis keunggulan di setiap wilayah menuju keunggulan kompetitif dengan membangun keterkaitan sistem produksi, distribusi, dan pelayanan di dalam negeri; (c) meningkatkan penguasaan, pemanfaatan, dan penciptaan pengetahuan; dan (d) membangun infrastruktur yang maju; serta (e) melakukan reformasi di bidang hukum dan aparatur negara (RPJPN 2005-2025). 
Untuk itu, dalam upaya membantu mewujudkan daya saing bangsa, politik hukum mengarahkan pembangunan hukum untuk mendukung terwujudnya pertumbuhan ekonomi yang berkelanjutan; mengatur permasalahan yang berkaitan dengan ekonomi, terutama dunia usaha dan dunia industri; serta menciptakan kepastian investasi, terutama penegakan dan perlindungan hukum. Pembangunan hukum juga diarahkan untuk menghilangkan kemungkinan terjadinya tindak pidana korupsi, serta mampu menangani dan menyelesaikan secara tuntas permasalahan yang terkait kolusi, korupsi, nepotisme (KKN). Pembangunan hukum dilaksanakan melalui pembaharuan materi hukum dengan tetap memerhatikan kemajemukan tatanan hukum yang berlaku dan pengaruh globalisasi sebagai upaya untuk meningkatkan kepastian dan perlindungan hukum, penegakan hukum, dan hakhak asasi manusia (HAM), kesadaran hukum, serta pelayanan hukum yang berintikan keadilan dan kebenaran, ketertiban dan kesejahteraan, dalam rangka penyelenggaraan negara yang semakin tertib, teratur, lancar, serta berdaya saing global (lampiran UU No. 17 Tahun 2007).

Pembangunan hukum yang dilakukan harus berkualitas 'reformasi'. Menurut Satjipto Rahardjo, reformasi hukum adalah perombakan hukum secara mendasar yang mempunyai kualitas 'paradigmatik' (Satjipto Rahardjo, 1998:6). Jadi reformasi hukum ekonomi adalah perombakan hukum ekonomi secara mendasar yang mempunyai kualitas 'paradigmatik'. Pembangunan hukum yang berkualitas paradigmatik demikian dilakukan guna mendukung terwujudnya daya saing bangsa sebagaimana tertuang dalam Rancangan Pembangunan Jangka Panjang 2005-2025 dan juga mewujudkan misi Presiden Joko Widodo, sebagaimana tertuang dalam Nawacita. Di samping itu, pembangunan hukum harus dilakukan secara 'revolusioner', dan pembangunan hukum dilakukan secara berkelanjutan, dengan mengacu pada fundamental hukum. Maksud dari fundamental hukum ini adalah menyangkut fungsi-fungsi primer hukum, yang meliputi: (1) penyediaan kaidah atau peraturan, (2) penerapan peraturan tersebut untuk mengkaidahi proses-proses dalam kehidupan sehari-hari, dan (3) penyediaan institusi pemutus untuk menganti- 
sipasi timbulnya permasalahan berhubungan dengan kedua butir pertama tersebut. Melakukan perencanaan pembangunan hukum adalah mengusahakan agar fungsi-fungsi tersebut dapat dijalankan secara baik sehingga tujuan bernegara hukum bisa tercapai (Satjipto Rahardjo, 1997:6).

Pembangunan hukum yang bersifat revolusioner yaitu mengubah secara sadar dan mendasar sistem hukum ekonomi yang selama ini berkualitas 'liberal' dan di bawah kendali negara-negara maju menjadi sistem hukum ekonomi yang berkualitas 'kekeluargaan (ukhuwah)' atau 'kerakyatan', sebagaimana tertuang dalam nilai-nilai Pancasila dan Pasal 33 UUD 1945. Pada tahun 1931 Mohammad Hatta memunculkan istilah 'perekonomian rakyat' sebagai lawan dikotomis dari 'perekonomian kolonial-kapital' sebagai titik tolak paham strukturalismenya. Hal ini senada dengan orientasi kerakyatan yang menjiwai kemerdekaan Indonesia untuk menggusur 'Daulat Tuanku’ dan menggantikannya dengan 'Daulat Rakyat'. Perekonomian koloniaal-kapital ini yang bermula dengan kolonialisme VOC dan Hindia Belanda berikut cultuurstelsel serta pelaksanaan UU Agraria 1870, boleh dibilang masih berkelanjutan (dalam wujud ekonomi kapitalistik dan konglomerasi ekonomi) hingga saat ini. (Sri Edi Swasono, 1992:80).

Sistem Hukum Ekonomi yang berkualitas 'kekeluargaan' atau 'kerakyatan’, ini sebenarnya juga merupakan sistem hukum yang tidak sekedar mengandalkan pada rule of law tapi lebih menaruh perhatian pada rule of moral atau rule of justice (Satjipto Rahardjo, 1995 \& 1996:6-7). Sistem hukum tersebut kemudian diintegrasikan secara timbal balik dengan sistem ekonomi Pancasila.

Pembangunan hukum yang bersifat 'revolusioner', pernah juga dilakukan oleh Jepang pada tahun 1868, Pada saat itu Kaisar Meiji mengeluarkan dokumen penting yang memuat kebijaksanaan dasar untuk mengubah Jepang Feodal menjadi negara modern, seperti penghapusan wilayah-wilayah feodal ke dalam propinsi, sistem militer wajib, sistem pajak terpusat, serta penghapusan hak-hak feodal dan kelas prajurit (K. Takayanagi, 1969:28). Dengan pendekatan 'revolusioner’ diharapkan pencapaian Visi Indonesia 2025 dan 
Nawacita Presiden Joko Widodo, dilandasi dan dituntun oleh suatu sistem hukum ekonomi yang bersumber dari Pancasila dan Undang-Undang Dasar 1945 serta norma-norma yang hidup di masyarakat (hukum adat atau hukum Islam).

Strategi pembangunan hukum ekonomi di Indonesia perlu juga memerhatikan konsep pembangunan hukum ekonomi berkelanjutan (sustainable economic law development), yang melakukan pembangunan tidak lagi hanya sekedar melakukan 'bongkar pasang' pasal-pasal dalam suatu undang-undang atau pembuatan undang-undang baru saja, tetapi juga memerhatikan dan memberdayakan daya dukung aspek yang lain, yaitu: 1) Politik hukum presiden dan wakil presiden, 2) menumbuhkan jiwa nasionalis pada anggota Legislatif 3.) reformasi substansi hukum, 4) mekanisme penyelesaian sengketa yang berwibawa dan efisien; yang aktifitasnya dilakukan secara kait mengkait, bersama-sama, dan terus menerus saling dukung mendukung serta konsisten.

\section{E. Simpulan}

Kualitas pembangunan hukum ekonomi dipengaruhi oleh respon bidang hukum terhadap tuntutan bidang ekonomi, kemampuan mengharmonisasikan tekanan globalisasi hukum dan kepentingan rakyat, serta tekanan sistem ekonomi kapitalis di Indonesia, menjadi salah satu kuncinya. Oleh karena itu, pembangunan hukum ekonomi harus dilakukan secara revolusioner dengan menetapkan terlebih dahulu sistem ekonomi Indonesia yang mendasarkan Pasal 33 Undang-Undang Dasar 1945, sehingga mampu menghasilkan sistem hukum ekonomi yang tidak mengabdi pada negara-negara maju dan perusahaanperusaahaan transnasional, tetapi lebih kearah berkualitas 'kekeluargaan (ukhuwah)' atau 'kerakyatan' dan mengabdi pada kepentingan rakyat, atau sistem hukum ekonomi yang ditempatkan sebagai panglima yang tidak sekedar mengandalkan pada rule of law tapi lebih menaruh perhatian pada rule of moral atau rule of justice. 
Di samping itu, perlu dilakukan pembangunan hukum ekonomi berkelanjutan (sustainable economic law development), yang melakukan pembangunan tidak lagi sekedar melakukan 'bongkar pasang' pasal-pasal dalam perundang-undangan atau pembuatan undang-undang baru saja, tapi juga memerhatikan dan memberdayakan aspek yang lain yang mencakup: reformasi substansi hukum ekonomi; tersedianya mekanisme penyelesaian sengketa yang berwibawa dan efisien; nasionalisme anggota Legislatif; dan adanya politik hukum presiden dan wakil presiden yang menjadikan hukum sebagai panglima yang memandu aktifitas ekonomi yang kondusif dan tegas menghukum bagi pelanggar hukum yang merusak ekonomi bangsa, yang semua aktifitasnya dilakukan secara konsisten sesuai visi dan misi serta RPJMN. Dengan pendekatan tersebut diharapkan pembangunan hukum ekonomi akan mampu mewujudkan daya saing bangsa, menghasilkan pertumbuhan ekonomi yang tinggi, dan juga mampu menjadikan hukum sebagai radar pemandu atau pengarah agar pertumbuhan ekonomi bukan sekedar angka-angka tapi berkualitas untuk mengurangi kemiskinan, menekan angka pengangguran, dan menyejahterakan rakyat.

\section{Daftar Pustaka}

Adi Sulistiyono. 2006. Mengembangkan Paradigma Non-Litigasi di Indonesia. Surakarta: Sebelas Maret University Press.

Adi Sulistiyono, Muhammad Rustamaji. 2009. Hukum Ekonomi Sebagai Panglima. Sidoarjo: Masmedia Buana Putaka.

Ahmad Erani Yustika. 2012. "Pembangunan dan Trilogi Ketimpangan”. Kompas, 12 Februari 2012.

Ana Rokhmatussa'dyah, Suratman. 2009. Hukum Investasi dan Pasar Modal. Jakarta: Sinar Grafika.

Badan Pembinaan Hukum Nasional Departemen Kehakiman RI. 1996. “Laporan Akhir : Penelitian Tentang Aspek Hukum Perdagangan Dikaitkan dengan Penanaman Modal Asing”, Jakarta: BPHN.

Badilum. 2014. Statistik Perkara Niaga. www.badilum.info/index.php/article/5

Bappenas, Direktorat Pendanaan Luar Negeri Bilateral Badan Perencanaan Pembangunan Nasional. 2007. "Pengelolaan Pendanaan Pembangunan Luar Negeri dalam Rangka Mengurangi Ketergantungan Pada Pinjaman Luar Negeri”. Jakarta: Laporan Kajian 2007. 
Berkowitz, Daniel. tt. "Economic Development, Legality, and the Transplant Effect”. William Davidson Institute: Working Paper Series No. 49.

Fernandez, Warren dan Sumiko Tan. 1998. Lee Kuan Yew: The Man and His Ideas. Singapore: The Straits Times Press.

Hermawan Kertajaya. 2014. “Markplus Conference 2015: Indonesia WOW!”. Jawa Pos, 11 Desember 2014.

Hilman Soelaiman. 2013. "Harmonisasi Hubungan Pemerintah Pusat dan Swasta Terkait Perizinan”. Jakarta: Media Indonesia, 5 Februari 2013.

Jonker Sihombing. 2010. Peran dan Aspek Hukum dalam Pembangunan Ekonomi. Bandung: Penerbit Alumni.

Kompas. 2007. Tajuk Rencana Kompas, “Fernandez dan Balas Budi Rakyat”. 31 Oktober 2007

Kompas. 2007. "Kaum Papa Dukung Fernandez, Kebijakan Suaminya Akan Diteruskan”. 31 Oktober 2007

Lili Rasjidi. Ira Thania Rasjidi. 2002. Pengantar Filsafat Hukum. Bandung: Penerbit Mandar Maju.

Muhammad Manduh, "Kantor Gameloft Indonesia Digrebek Polisi”, Metrotvnews.Com. 10 November $2014 \quad 21: 52$ wib (http://id.gamesinasia.com/).

Muhammad Rustamaji. 2015. "Memertimbangkan Filsafat Kritis dan Deep Ecology dalam Pergumulan Masyarakat Ekonomi Asean”, Prosiding Seminar Nasional Kesiapan Indonesia: Harmonisasi Hukum Negara-negara Asean Menuju Komunitas Asean 2015. Surakarta: Fakultas Hukum, Universitas Muhammadiyah Surakarta (UMS).

Nicholas Stern. 2003. Investment Climate: Lessons and Challenges. Distiguished Lecture Series 19. Egyp: ECES Publication

North, Douglass. 1990. Institutions, Institutional Change, and Economic Performance. Cambridge: Cambridge University Press.

Rizal Mallarangeng. 2002. Mendobrak Sentralisme Rezim. Jakarta: Penerbit Kepustakaan Populer Gramedia dan Freddom Institute.

Robert Bala. 2007. “Argentina dan Krisis Abadi”, Kompas, 31 Oktober 2007

RPJP Nasional dan Periodisasi Perencanaan Pembangunan Jangka Menengah Nasional 5 (lima) Tahunan (RPJM Nasional I Tahun 2005-2009, RPJM Nasional II Tahun 2010-2014, RPJM Nasional III Tahun 2015-2019, RPJM Nasional IV Tahun 2020-2024).

Satjipto Rahardjo. 1993. "Tinjauan Kritis Terhadap Pembangunan Hukum Indonesia”. Analisis CSIS No. 1, 1993.

1995. "Liberalisme, Kapitalisme dan Hukum Indonesia". Kompas, 16 Januari 1995. 1995.

1995. "Rule of Law: Mesin atau Kreativitas”. Kompas, 3 Mei

1996. “Negara Hukum Tanpa Moral dan Disiplin”. Kompas, 23 Februari 1996, “Hukum Sebagai Keadilan, Permainan dan Bisnis”. Kompas, 4 April 1996.

1996. "Transformasi Nilai-nilai dalam Pembentukan Hukum Nasional”. Majalah Badan Pembinaan Hukum Nasional No. 2, 1996. 
1997. “Fundamental Hukum”. Jakarta: Kompas, 20 Oktober 1997. 1998. “Keluasan Reformasi Hukum”. Jakarta: Kompas, 8 Mei 1998.

Septian Deny,. 2014. “Daya Saing RI Meningkat Karena Investasi Asing Terus Tumbuh”. Jakarta: Liputan6.com. on Sep 04, 2014 at 10:01 WIB.

Sri Edi Swasono. 1992. Dari Daulat Tuanku ke Daulat Rakyat. Jakarta: Penerbit Universitas Indonesia

Stern, Nicholas. 2001. A Strategy for Delelopment. Washington DC:ABCDE Keynote Address, World Bank

Takayanagi, K.. 1969. "A Century of Innovation : The Development of Japanese Law, 1886-1961”, dalam Law in Japan, von Mehren (ed), 1969.

Tulus Tambunan. 2006. "Iklim Investasi Di Indonesia: Masalah, Tantangan dan Potensi”. www.kadin-indonesia.or.id.

Undang-undang Negara Republik Indonesia Nomor 17 Tahun 2007 tentang RPJP 2005-2025.

World Bank Group. 2015. Doing Business 2015, Going Beyond Efficiency (Comparing Business Regulations for Domestic Firm in 189 Economic). A World Bank Group Flagship Report $12^{\text {th }}$ Edition. 